\title{
EDUKASI DENGAN MEDIA KOMIK TERHADAP EFIKASI DIRI UPAYA PENCEGAHAN KEKERASAN SEKSUAL PADA ANAK USIA SEKOLAH
}

\author{
Ni Gusti Ayu Santika Dewi ${ }^{1}$, Putu Susy Natha Astini ${ }^{2}$, Ida Erni Sipahutar ${ }^{3}$ \\ 1,2,3 Jurusan Keperawatan Politeknik Kesehatan Denpasar \\ Denpasar, Bali, Indonesia
}

$$
\begin{gathered}
\text { E-mail: santikadewi58@yahoo.com }{ }^{1} \text {, susynathaastini@gmail.com }{ }^{2}, \\
\text { ernii61@yahoo.com }{ }^{3}
\end{gathered}
$$

\begin{abstract}
Sexual violence is any sexual act, pursues to commit sexual acts, comments or suggests unintentional sexual behaviour, and assaults for sexual intimacy with coercion to children. The impacts of sexual violence can ruin the psychosocial, future growth and development of children. This research purposes to determine the impacts of giving education by using comic as media on the self-efficacy to prevent sexual violence for school-age children. This research is pre-experimental designs with the design of one group pre-test post-test design. The sample amounted to 70 people using the startified random sampling technique. The Wilcoxon test tested the results of the study of $\rho$-value was 0,001, it means that there was a significant influence on giving education by using comic as media on the self-efficacy to prevent sexual violence for school-age children at 3 Batubulan Kangin Elementary School in 2019. Based on the results of the research, it is expected that it will be a guideline for teachers to educate other students by developing similar media.
\end{abstract}

\section{Keywords : Child Sexual Violence, Self Efficacy, Comic Media}

\begin{abstract}
Abstrak.Kekerasan seksual merupakan setiap tindakan seksual, usaha melakukan tindakan seksual, komentar atau menyarankan untuk berperilaku seksual yang tidak disengaja, dan tindakan pelanggaran untuk melakukan hubungan seksual dengan paksaan kepada anak. Dampak dari kekerasan seksual dapat menghancurkan psiokososial, pertumbuhan dan perkembangan anak di masa depan. Penelitian ini bertujuan mengetahui adanya pengaruh pemberian edukasi dengan media komik terhadap efikasi diri upaya pencegahan kekerasan seksual pada anak usia sekolah. Jenis penelitian ini preexperimental designs dengan rancangan one group pre-test post-test design. Sampel berjumlah 70 orang dengan menggunakan teknik startified random sampling. Hasil penelitian diuji dengan uji Wilcoxon didapatkan nilai $\rho$-value 0,001 yang berarti ada pengaruh signifikan pemberian edukasi dengan media komik terhadap efikasi diri upaya pencegahan kekerasan seksual pada anak usia sekolah di SDN 3 Batubulan Kangin tahun 2019. Hasil penelitian diharapkan sebagai pedoman guru memberikan edukasi seksual bagi siswa dengan mengembangkan media yang serupa.
\end{abstract}

\section{Kata Kunci : Kekerasan Seksual, Efikasi Diri, Media Komik}


Ni Gusti Ayu Santika Dewi, Putu Susy Natha Astini, Ida Erni Sipahutar. Desember 2020.13 (2).59-68

\section{PENDAHULUAN}

Kekerasan seksual didefinisikan sebagai setiap tindakan seksual, usaha melakukan tindakan seksual, komentar atau menyarankan untuk berperilaku seksual yang tidak disengaja ataupun sebaliknya, tindakan pelanggaran untuk melakukan hubungan seksual dengan paksaan kepada seseorang ${ }^{(1)}$.

Kekerasan seksual dapat berupa kontak fisik seperti pemerkosaan dan perbuatan yang tidak harus melibatkan kontak fisik antara anak dan pelaku seperti melibatkan anak dalam pembuatan konten pornografi dan menonton aktivitas-aktivitas seksual $^{(2)}$.

Prevalensi global tejadinya kekerasan seksual yang melibatkan sentuhan pada anak laki-laki dan perempuan dibawah umur 18 tahun sekitar 73 juta (7\%) anak laki-laki dan 150 juta (14\%) anak perempuan. Anak perempuan memiliki risiko lebih besar mengalami kekerasan seksual dibandingkan anak laki-laki. Hampir $21 \%$ perempuan di beberapa negara dilaporkan pernah mengalami kekerasan seksual sebelum umur 15 $\operatorname{tahun}^{(3)}$.

Kekerasan seksual terhadap anak di Indonesia dari tahun 2013 ke 2014 meningkat $100 \%$ baik itu anak sebagai korban ataupun sebagai pelaku kekerasan seksual. Kasus pengaduan anak berdasarkan klaster perlindungan anak yaitu Anak Berhadapan dengan Hukum $(\mathrm{ABH})$ dari tahun 2011 sampai 2016 sebanyak 7967 kasus. Kasus pengaduan anak berdasarkan klaster perlindungan anak yaitu kategori Pornografi dan Cyber Crime dari tahun 2011 sampai 2016 sebanyak 1809 kasus $^{(4)}$.

Bali termasuk ke dalam sepuluh besar daerah dengan tingkat kekerasan pada anak tertinggi di
Indonesia. Industri pariwisata menjadi salah satu pemicu tingginya kasus kekerasan anak di Pulau Dewata. Kasus pedofilia merupakan kasus terbanyak di Bali dengan jumlah kasus pelecehan di lingkungan sekolah mencapai $20 \%$ dari 300 kasus $\left({ }^{5)}\right.$. Kasus pengaduan anak di Bali berdasarkan klaster perlindungan anak yaitu pada kategori anak berhadapan dengan hukum (ABH) dari tahun 2011 sampai 2016 sebanyak 182 kasus dan pada kategori pornografi dan cyber crime sebanyak 59 kasus $^{(4)}$.

Kasus kekerasan terhadap anak sebagai korban di Kabupaten Gianyar terus mengalami peningkatan setiap tahunnya. Berdasarkan data hingga Agustus 2018 sudah tercatat 12 orang anak sebagai korban kekerasan yang di tangani Dinas Pemberdayaan Perempuan Perlindungan Anak pengendalian Penduduk dan Keluarga Berencana (P3AP2KB) Kabupaten Gianyar. Dari tujuh kecamatan di Gianyar, Kecamatan Sukawati terdapat kasus kekerasan dengan korban anak paling banyak ${ }^{(6)}$.

Kekerasan seksual terhadap anak adalah kenyataan yang menakutkan dan tidak menyenangkan karena dampaknya yang bisa menghancurkan psiokososial, pertumbuhan dan perkembangannya di masa depan. Pendidikan seksual dan pemberian informasi tentang permasalahan kekerasan seksual dapat mencegah resiko perilaku kekerasan seksual ${ }^{(7)}$.

Anak sekolah dasar termasuk ke dalam fase latensi dimana semua aktivitas dan fantasi seksual seakanakan tertekan, adanya keingintahuan anak tentang seksualitas tetap berlanjut, dan anak-anak juga menerima informasi tentang seksualitas dari teman sebayanya yang sering menyesatkan ${ }^{(8)}$. 
Ni Gusti Ayu Santika Dewi, Putu Susy Natha Astini, Ida Erni Sipahutar.

Desember 2020.13 (2).59-68

Masa sekolah dasar dikenal sebagai masa peralihan dari masa kanak-kanak awal ke masa kanakkanak akhir sampai menjelang masa pra-pubertas. Usia ini anak perlu mempersiapkan diri untuk memasuki masa pubertasnya seiring dengan pertumbuhan dan perkembangan yang terjadi pada dirinya maka siswa perlu diberikan informasi mengenai edukasi seksual $^{(9)}$.

Pendidikan seksual dan pemberian informasi tentang permasalahan kekerasan seksual dapat mencegah resiko perilaku kekerasan seksual. Pendidikan seks pada anak harus diberikan agar anak tidak salah melangkah. Anak-anak yang kurang pengetahuan tentang seks jauh lebih beresiko untuk menjadi korban mudah dibodohi oleh para pelaku kekerasan seksual. Untuk melindungi anak dari segala sesuatu yang tidak diinginkan maka anak perlu diberikan edukasi $^{(7)}$.

Kemampuan diri pada anak untuk melakukan pencegahan kekerasan seksual dapat dilakukan jika anak memiliki efikasi diri (keyakinan diri). Istilah self efficacy mengacu pada keyakinan (beliefs) tentang kemampuan seseorang untuk mengorganisasikan dan melaksanakan tindakan untuk pencapaian hasil $^{(10)(11)}$.

Perkembangan anak usia sekolah dasar lebih menyukai cerita yang benarbenar terjadi atau cerita yang masuk akal $^{(12)}$. Komik merupakan media pembelajaran yang menarik bagi anak untuk mempelajari pendidikan seksual. Sebagai media pembelajaran, komik pendidikan merupakan salah satu jenis media yang dapat diterapkan dalam proses pembelajaran.

Penelitian ini memberikan edukasi dengan media komik kepada anak usia sekolah dasar mengenai upaya pencegahan kekerasan seksual.
Penelitian ini secara umum bertujuan untuk mengetahui adanya pengaruh pemberian edukasi dengan media komik terhadap efikasi diri upaya pencegahan kekerasan seksual pada anak usia sekolah di SDN 3 Batubulan Kangin.

\section{METODE}

Penelitian ini menggunakan rancangan penelitian pre experimental designs yaitu rancangan one group pre-test posttest design. Penelitian ini dilaksanakan di SDN 3 Batubulan Kangin. Populasi pada penelitian ini adalah siswa sekolah dasar kelas 4 dan 5 SDN 3 Batubulan Kangin yang berjumlah 85 orang. Sampel penelitian berjumlah 70 orang diambil dari populasi siswa kelas 4 dan 5 SDN 3 Batubulan Kangin yang bersedia menjadi responden dan menandatangani informed consent. Cara pengambilan sampel pada penelitian ini dengan menggunakan probability sampling. Teknik pengambilan sampel dilakukan secara acak atau random maka setiap anggota populasi mempunyai peluang sama untuk dipilih menjadi anggota sampel. Jenis probability sampling yang digunakan pada penelitian ini yaitu startified random sampling. Data yang dikumpulkan dengan cara metode wawancara bersama kepala sekolah SDN 3 Batubulan Kangin dan lembar kuesioner efikasi diri upaya pencegahan kekerasan seksual pada anak usia sekolah. Kuesioner menggunakan dichotomy question memuat dimensi efikasi diri yaitu magnitude, generality, dan strength berjumlah 20 pernyataan dengan skala Likert. Teknik analisis data univariat menggunakan kategori tingkat efikasi diri anak usia sekolah dibagi manjadi empat tingkatan yang didasarkan pada nilai 
Ni Gusti Ayu Santika Dewi, Putu Susy Natha Astini, Ida Erni Sipahutar.

Desember 2020.13 (2).59-68

persentase dan teknik analisis bivariat menggunakan komputer dengan uji statistik Wilcoxon

HASIL DAN PEMBAHASAN

Karakteristik subjek penelitian

disajikan dalam tabel berikut:

Tabel 1. Distribusi Frekuensi Subjek Penelitian

Berdasarkan Umur dan Jenis Kelamin di SDN 3 Batubulan Kangin Tahun 2019

\begin{tabular}{|c|c|c|c|}
\hline \multicolumn{2}{|c|}{ Karakteristik } & $\begin{array}{c}\text { Frekue } \\
\text { nsi } \\
\text { (n) }\end{array}$ & $\begin{array}{c}\text { Persent } \\
\text { ase } \\
(\%)\end{array}$ \\
\hline \multirow{4}{*}{ Umur } & $\begin{array}{c}9 \\
\text { Tahun }\end{array}$ & 5 & 7,1 \\
\hline & $\begin{array}{c}10 \\
\text { Tahun }\end{array}$ & 23 & 32,9 \\
\hline & $\begin{array}{c}11 \\
\text { Tahun }\end{array}$ & 38 & 54,3 \\
\hline & $\begin{array}{c}12 \\
\text { Tahun }\end{array}$ & 4 & 5,7 \\
\hline \multicolumn{2}{|c|}{ Total } & 70 & 100 \\
\hline \multirow{2}{*}{$\begin{array}{l}\text { Jenis } \\
\text { Kela } \\
\text { min }\end{array}$} & $\begin{array}{l}\text { Laki- } \\
\text { Laki }\end{array}$ & 31 & 44,3 \\
\hline & $\begin{array}{c}\text { Peremp } \\
\text { uan }\end{array}$ & 39 & 55,7 \\
\hline \multicolumn{2}{|c|}{ Total } & 70 & 100 \\
\hline
\end{tabular}

Berdasarkan tabel 1 karakteristik subjek penelitian berdasarkan umur dengan rentang 9 tahun sampai 12 tahun didapatkan hasil responden sebagian besar berumur 11 tahun sebanyak 38 orang $(54,3 \%)$ dan responden sebagian besar berjenis kelamin perempuan berjumlah 39 orang $(55,7 \%)$.

\footnotetext{
Efikasi diri upaya pencegahan kekerasan seksual pada anak usia sekolah sebelum diberikan edukasi dengan media komik, yaitu:
}
Tabel 2. Distribusi Frekuensi Responden Berdasarkan Efikasi Diri Upaya Pencegahan Kekerasan Seksual pada Anak Usia Sekolah Sebelum Diberikan Edukasi dengan Media Komik di SDN 3 Batubulan Kangin Tahun 2019

\begin{tabular}{|c|c|c|}
\hline $\begin{array}{c}\text { Efikasi Diri } \\
\text { Upaya } \\
\text { Pencegahan } \\
\text { Kekerasan } \\
\text { Seksual }\end{array}$ & $\begin{array}{c}\text { Frekuen } \\
\text { si (n) }\end{array}$ & $\begin{array}{c}\text { Persenta } \\
\text { se }(\boldsymbol{\%})\end{array}$ \\
\hline Sangat baik & 10 & 14,3 \\
\hline Baik & 27 & 38,6 \\
\hline Tidak baik & 25 & 35,7 \\
\hline $\begin{array}{c}\text { Sangat tidak } \\
\text { baik }\end{array}$ & 8 & 11,4 \\
\hline Total & 70 & 100 \\
\hline
\end{tabular}

\section{Berdasarkan tabel diatas dapat}

dilihat bahwa hasil penelitian menunjukkan efikasi diri upaya pencegahan kekerasan seksual pada anak usia sekolah sebelum diberikan edukasi dengan media komik paling banyak berada pada kategori baik yaitu 27 orang $(38,6 \%), 25$ siswa berada pada kategori tidak baik $(35,7 \%), 10$ orang siswa berada pada kategori sangat baik $(14,3 \%)$, sedangkan paling sedikit berada pada kategori sangat tidak baik sebanyak 8 orang $(11,4 \%)$. Efikasi diri upaya pencegahan kekerasan seksual pada anak usia sekolah setelah diberikan edukasi dengan media komik, yaitu: 
Ni Gusti Ayu Santika Dewi, Putu Susy Natha Astini, Ida Erni Sipahutar.

Desember 2020.13 (2).59-68

Tabel 3. Distribusi Frekuensi Responden Berdasarkan Efikasi Diri Upaya Pencegahan Kekerasan Seksual pada Anak Usia Sekolah Sesudah Diberikan Edukasi dengan Media Komik di SDN 3 Batubulan Kangin Tahun 2019

\begin{tabular}{|c|c|c|}
\hline $\begin{array}{c}\text { Efikasi Diri } \\
\text { Upaya } \\
\text { Pencegahan } \\
\text { Kekerasan } \\
\text { Seksual }\end{array}$ & $\begin{array}{c}\text { Frekuen } \\
\text { si (n) }\end{array}$ & $\begin{array}{c}\text { Persenta } \\
\text { se (\%) }\end{array}$ \\
\hline Sangat baik & 66 & 94,3 \\
\hline Baik & 4 & 5,7 \\
\hline Tidak baik & - & - \\
\hline $\begin{array}{c}\text { Sangat tidak } \\
\text { baik }\end{array}$ & - & - \\
\hline Total & 70 & 100 \\
\hline
\end{tabular}

Berdasarkan tabel diatas menunjukkan efikasi diri upaya pencegahan kekerasan seksual pada anak usia sekolah setelah diberikan edukasi dengan media komik didapatkan hasil sebagian besar berada pada kategori sangat baik sebanyak 66 orang $(94,3 \%)$, terdapat 4 orang siswa berada pada kategori baik (5,7\%). Tidak ada siswa yang berada pada kategori efikasi diri tidak baik dan sangat tidak baik.
Tabel

4. Hasil Analisis Pengaruh Pemberian Edukasi dengan Media Komik terhadap Efikasi Diri Upaya Pencegahan Kekerasan Seksual pada Anak Usia Sekolah di SDN 3 Batubulan Kangin Tahun 2019

\begin{tabular}{|c|c|c|c|}
\hline $\begin{array}{c}\text { Post - } \\
\text { Pre }\end{array}$ & $\begin{array}{c}\text { Frekuen } \\
\text { si (n) }\end{array}$ & $\begin{array}{c}\text { Persentas } \\
\text { e (\%) }\end{array}$ & $\begin{array}{c}\boldsymbol{\rho} \text { - } \\
\text { value }\end{array}$ \\
\hline $\begin{array}{c}\text { Post test } \\
\text { < Pre test }\end{array}$ & 0 & 0 & \\
\hline $\begin{array}{c}\text { Post test } \\
\text { Pre test }\end{array}$ & 60 & 85,7 & \multirow{2}{*}{0,001} \\
\cline { 1 - 3 } $\begin{array}{c}\text { Post test } \\
\text { Pre test }\end{array}$ & 10 & 14,3 & \\
\hline Total & 70 & 100 & \\
\hline
\end{tabular}

Berdasarkan tabel diatas dapat diketahui perbandingan nilai pre test dan post test siswa setelah diberikan edukasi dengan media komik yaitu tidak ada nilai post test yang lebih kecil dibandingkan nilai pre test, sebagian besar siswa mengalami peningkatan efikasi diri upaya pencegahan kekerasan seksual sebelum dan sesudah diberikan edukasi dengan media komik dilihat dari hasil analisis nilai post test yang lebih besar dari nilai pre test sebanyak 60 orang $(85,70 \%)$.

Hasil penelitian ini diuji dengan uji statistik Wilcoxon dan didapatkan nilai $\rho$-value pada kolom Sig. $=0,001<$ alpha $(0,05)$ yang berarti hipotesis penelitian diterima yang menunjukkan adanya pengaruh yang signifikan atau bermakna pemberian edukasi dengan media komik terhadap efikasi diri upaya pencegahan kekerasan seksual pada anak usia sekolah di SDN 3 Batubulan Kangin Tahun 2019. 
Ni Gusti Ayu Santika Dewi, Putu Susy Natha Astini, Ida Erni Sipahutar.

Desember 2020.13 (2).59-68

Efikasi diri upaya pencegahan kekerasan seksual pada anak usia sekolah sebelum diberikan edukasi dengan media komik

Efikasi diri upaya pencegahan kekerasan seksual pada anak usia sekolah sebelum diberikan edukasi dengan media komik paling banyak berada pada kategori baik yaitu 27 orang $(38,6 \%), 25$ siswa berada pada kategori tidak baik $(35,7 \%), 10$ orang siswa berada pada kategori sangat baik $(14,3 \%)$, sedangkan paling sedikit berada pada kategori sangat tidak baik sebanyak 8 orang $(11,4 \%)$.

Hasil diatas membuktikkan bahwa kategori efikasi diri upaya pencegahan kekerasan seksual siswa masih bervariasi. Sebagian besar siswa berada pada kategori baik dan tidak baik, namun masih terdapat siswa berada pada kategori efikasi diri sangat tidak baik yang menunjukkan efikasi diri pada anak usia sekolah merupakan hal yang penting dalam upaya pencegahan kekerasan seksual yang dapat terjadi dimana dan kapan saja. Hasil tersebut menunjukkan sebagian besar siswa masih merasa bingung dengan apa yang boleh dan tidak boleh dilakukan untuk menghindari ancaman terjadinya kekerasan seksual.

Promosi kesehatan di sekolah merupakan langkah strategis dalam upaya peningkatan kesehatan siswa. Sekolah adalah sebagai perpanjangan tangan keluarga dalam meletakkan dasar perilaku untuk kehidupan anak selanjutnya, ternasuk perilaku kesehatan. Promosi kesehatan di sekolah pada prinsipnya adalah menciptakan sekolah sebagai komunitas yang mampu meningkatkan kesehatannya (health promoting school). Setiap orang termasuk anggota masyarakat sekolah dalam memelihara dan meningkatkan kesehatannya sendiri memerlukan keterampilan atau kemampuan. Kemampuan memelihara dan meningkatkan kesehatan harus dikembangkan sedini mungkin, termasuk pada saat masih menjadi murid sekolah. Oleh sebab itu, pendidikan atau penyuluhan kesehatan di sekolah penting dilakukan yaitu salah satunya menyangkut pendidikan seksual ${ }^{(13)}$.

Penelitian yang berjudul "Penerapan Pendidikan Seks Underwear Rules terhadap Pencegahan Kekerasan Seksualpada Anak dan Orang Tua di SDN 52 Welonge" didapatkan hasil pengetahuan pencegahan kekerasan seksual pada anak sebelum diberikan pendidikan kesehatan dengan kategori baik sebanyak 65 responden $(74,7 \%)$ dan 22 responden $(25,3 \%)$ dengan kategori kurang.

Menurut peneliti upaya pemberdayaan yang dilakukan untuk meningkatkan efikasi diri dalam upaya pencegahan kekerasan seksual adalah memberikan pendidikan kesehatan dengan media komik. Anak yang memiliki efikasi diri tinggi maka memiliki kemampuan untuk menolong dirinya sendiri. Anak yang memiliki efikasi diri tinggi dapat melakukan pencegahan kekerasan seksual. Pemberian edukasi seksual dengan media komik ini berupa pemberian informasi mengenai bagian tubuh yang sangat pribadi, batasan sentuhan aman, tindakan mencegah kekerasan seksual, dan antisipasi gambar pornografi sehingga anak mempunyai kemampuan dan kepercayaan diri untuk mengambil tindakan yang rasional.

Efikasi diri upaya pencegahan kekerasan seksual pada anak usia sekolah setelah diberikan edukasi dengan media komik

Hasil penelitian ini menunjukkan efikasi diri upaya pencegahan kekerasan seksual pada anak usia sekolah setelah diberikan edukasi dengan media komik didapatkan hasil sebagian besar berada pada kategori sangat baik sebanyak 66 orang 
Ni Gusti Ayu Santika Dewi, Putu Susy Natha Astini, Ida Erni Sipahutar.

Desember 2020.13 (2).59-68

$(94,3 \%)$, terdapat 4 orang siswa berada pada kategori baik $(5,7 \%)$. Tidak ada siswa yang berada pada kategori efikasi diri tidak baik dan sangat tidak baik.

Hasil diatas membuktikkan bahwa telah terjadi peningkatan efikasi diri siswa setelah diberikan edukasi dengan media komik dimana sebagian besar telah berada pada kategori sangat baik yakni sebanyak 66 orang $(94,3 \%), 4$ orang siswa berada pada kategori baik $(5,7 \%)$, dan tidak ada lagi siswa yang berada pada kategori efikasi diri tidak baik dan sangat tidak baik. Hasil tersebut dikarenakan tingkat antusias anak-anak saat berlangsungnya penelitian. Anakanak tampak kooperatif mengikuti kegiatan walaupun terdapat beberapa anak yang kurang fokus menyimak materi yang diberikan. Penyebab terjadinya hal tersebut dikarenakan terdapat hambatan pada proses komunikasi antara siswa dengan peneliti selama berlangsungnya kegiatan pemberian edukasi dengan media komik yaitu beberapa anak lebih memilih bermain dengan temannya sehingga tujuan dari kegiatan belum tercapai secara maksimal, maka dari itu diharapkan kepada guru sekolah dasar agar dalam pemberian materi kekerasan seksual dan upaya pencegahannya dengan menggunakan media komik ini dapat diselipkan dalam pelajaran Ilmu Pengetahuan Alam dan Olahraga di sekolah dengan tetap mengkondisikan fokus anak-anak ke materi sehingga target upaya pencegahan kekerasan seksual anak usia sekolah dengan kategori sangat baik dapat tercapai secara maksimal.

Pemberian edukasi dengan media komik ini siswa diberikan komik yang berjudul "Pssst... Ada Bahaya Disekitar Kita” berjumlah 20 halaman yang akan dibaca oleh peserta dengan waktu 45 menit -1 jam. Komik ini berisikan informasi pendidikan seksual dan upaya pencegahan kekerasan seksual dengan gambar yang menarik. Komik edukasi upaya pencegahan dan perlindungan kekerasan seksual terhadap anak ini diperoleh pada website http://dp3akb.jabarprov.go.id/downloa d -komik-kta/. Setelah diberikan edukasi dengan media komik, siswa diberikan post-test dengan menjawab pernyataan dalam kuesioner. Kegiatan ini akan dilakukan dalam satu kali pertemuan.

Penelitian yang berjudul "Penerapan Pendidikan Seks Underwear Rules terhadap Pencegahan Kekerasan Seksual pada Anak dan Orang Tua di SDN 52 Welonge" didapatkan hasil pengetahuan pencegahan kekerasan seksual pada anak setelah diberikan pendidikan kesehatan dengan kategori baik sebanyak 81 responden $(93,1 \%)$ dan kategori kurang sebanyak 6 responden $(6,9 \%)$.

Menurut peneliti pemberian edukasi dengan media komik ini bukan sekedar kegiatan yang menyenangkan, tetapi juga bermanfaat untuk anak. Pemberian edukasi dengan media komik ini dapat membuat anak-anak lebih memahami materi yang disampaikan dengan memadukan kekuatan gambar dan tulisan, yang dirangkai dalam suatu alur cerita gambar membuat informasi lebih mudah diserap. Komik juga merupakan media komunikasi visual dan lebih daripada sekedar cerita bergambar yang ringan dan menghibur. Sebagai media komunikasi visual, komik dapat diterapkan sebagai alat bantu pendidikan dan mampu menyampaikan informasi secara efektif dan efisien.

Pengaruh pemberian edukasi dengan media komik terhadap efikasi diri upaya pencegahan kekerasan seksual pada anak usia sekolah

Komik sebagai media pembelajaran sudah lama diterapkan dan memberikan dampak yang positif selama proses pembelajaran. Media komik selain menyenangkan, juga dapat meningkatkan 
Ni Gusti Ayu Santika Dewi, Putu Susy Natha Astini, Ida Erni Sipahutar.

Desember 2020.13 (2).59-68

minat membaca, serta mengembangkan perbendaharaan kosa kata dalam berbahasa. Komik digunakan sebagai langkah awal untuk membangkitkan minat membaca siswa, terutama bagi yang tidak suka membaca. komik juga merupakan jembatan untuk membaca buku yang lebih serius, menghibur, menyenangkan dan edukatif ${ }^{(14)}$.

Hasil analisis uji statistik wilcoxon didapatkan nilai $\rho$-value pada kolom Sig. $(2$-tailed $)=0,001<$ alpha $(0,05)$ hal ini berarti hipotesis penelitian diterima yang menunjukkan adanya pengaruh signifikan atau bermakna pemberian edukasi dengan media komik terhadap efikasi diri upaya pencegahan kekerasan seksual pada anak usia sekolah di SDN 3 Batubulan Kangin Tahun 2019. Peningkatan efikasi diri siswa dalam upaya pencegahan kekerasan seksual sebelum dan sesudah pemberian edukasi dengan media komik dilihat dari hasil nilai post test yang lebih besar dari nilai pre test yaitu sebanyak 60 orang $(85,7 \%)$. Hasil penelitian ini menunjukkan edukasi dengan media komik

memberikan pengaruh dalam peningkatan efikasi diri upaya pencegahan kekerasan seksual siswa sekolah dasar. Walaupun peningkatan kategori sangat baik tidak dialami oleh seluruh siswa kelas IV dan V, namun metode ini telah meningkatkan sebagian besar efikasi diri siswa yang sebelumnya berada pada kategori sangat tidak baik dan tidak baik menjadi baik dan sangat baik.

Penelitian ini senada dengan penelitian yang berjudul "Efektivitas Komik Terhadap Self Efficacy Upaya Pencegahan Kekerasan pada Anak Usia Sekolah" didapatkan hasil ratarata self efficacy responden sebelum dan setelah diberikan pendidikan kesehatan dengan media komik terjadi peningkatan rerata sebesar 6,62 dan $\rho$ value 0,001 . Hasil tersebut menggambarkan adanya pengaruh yang signifikan antara self efficacy sebelum dan sesudah pendidikan kesehatan melalui $\operatorname{komik}^{(14)}$.

Penelitian lain yang berjudul "Penerapan Pendidikan Seks Underwear Rules terhadap Pencegahan Kekerasan Seksual pada Anak dan Orang Tua di SDN 52 Welonge" didapatkan hasil analisis bivariat antara variabel pengaruh pendidikan seks (underwear rules) terhadap pencegahan kekerasan seksual pada anak di SDN 52 Welonge dengan uji statistik Wilcoxon diperoleh nilai $\rho$-value $=0,002$ yang menunjukkan bahwa terdapat pengaruh pendidikan seks (underwear rules) terhadap pencegahan kekerasan seksual pada anak di SDN 52 Welonge kabupaten Soppeng ${ }^{(15)}$.

Efikasi diri seseorang dapat dipengaruhi atau dibentuk oleh adanya pengalaman diri sendiri, pengalaman orang lain yang dirasakan oleh diri sendiri, persuasi emosi dan verbal, dan perubahan fisik. Hal yang paling kuat mempengaruhi self efficacy adalah pengalaman diri. Pengalaman diri tersebut dapat ditingkatkan dengan menguasai suatu pengalaman tertentu. Pengalaman diri tersebut dapat diperoleh dengan membaca komik. Komik merupakan media yang dapat menambah pengetahuan dan pengalaman, melakukan interpretasi, dan menilai hasil yang ada. Komik dapat dijadikan media pilihan yang digunakan oleh pendidik sebagai media inovatif perkembangan pengetahuan anak. Anak usia sekolah yang memiliki banyak pengetahuan akan meningkatkan self efficacy seorang anak terhadap suatu hal, dalam hal ini terhadap upaya pencegahan kekerasan seksual pada anak $^{(10)}$.

Hasil penelitian dan teori yang telah dijelaskan diatas, maka peneliti berpendapat bahwa anak-anak usia 9-12 tahun sangat baik untuk diberikan pengembangan materi kekerasan seksual dan upaya pencegahannya melalui pemberian edukasi dengan media komik. Komik edukasi upaya 
Ni Gusti Ayu Santika Dewi, Putu Susy Natha Astini, Ida Erni Sipahutar.

Desember 2020.13 (2).59-68

pencegahan dan perlindungan kekerasan seksual terhadap anak ini dapat di akses pada website http://dp3akb.jabarprov.go.id/downloa d -komik-kta/. Pemberian edukasi seksual dalam upaya pencegahan kekerasan seksual ini dapat menggunakan media lain sebagai acuan untuk meningkatkan efikasi diri anak di komunitas sekolah.

\section{SIMPULAN}

Hasil penelitian ini disimpulkan bahwa ada pengaruh signifikan atau bermakna pemberian edukasi dengan media komik terhadap efikasi diri upaya pencegahan kekerasan seksual pada anak usia sekolah yang menggunakan uji Wilcoxon dengan nilai $\rho$-value 0,001 .

\section{UCAPAN TERIMAKASIH}

Penulis mengucapkan terima kasih kepada Direktur Poltekkes Denpasar, Ketua Jurusan Keperawatan, Ketua Program Studi D-IV Jurusan Keperawatan, Dosen Pembimbing Skripsi, serta Dosen Jurusan Keperawatan yang telah membimbing dan memberikan pengetahuan dalam menyelesaikan skripsi ini.

\section{ETIKA PENELITIAN}

Ketua KomisiEtik Penelitian

Kesehatan Poltekkes Denpasar memutuskan protokol penelitian yang berjudul "Pengaruh Pemberian Edukasi dengan Media Komik terhadap Efikasi Diri Upaya Pencegahan Kekerasan Seksual pada Anak Usia Sekolah" Laik Etik dengan Nomor: LB.02.03/EA/KEPK/0247/ 2019.

\section{SUMBER DANA}

Penelitian ini menggunakan sumber dana pribadi (swadana).

\section{DAFTAR RUJUKAN}

1. WHO. Understanding and
Addressing Violence Against WOmen. 2012;1-12. Available from:

http://apps.who.int/iris/bitstream /handle/10665/77434/WHO_Rh r_12.37_eng.pdf?sequence $=1$

2. International E. Melindungi Anak-Anak Dari Eksploitasi Seksual dan Kekerasan Seksual Dalam Situasi Bencana dan Gawat Darurat [Internet]. Medan: Restu Printing; 2006. Available from: http://bp3akb.jabarprov.go.id/w p-content/uploads/delightfuldownloads/2016/06/melindungianak-anak-dari-eska.pdf.

3. UNICEF. No TitleSexual Violence Against Children In The Caribbean Report 2012 [Internet]. Bridgetown. 2013. Available from: http://www.unicef.org/easternca ri

bbean/Ecao_Sexual_Violence_a $\mathrm{g}$ ainst_Children_in_the_Caribbea n. pdf

4. KPAI. Data Kasus Perlindungan Anak Berdasarkan Lokasi Pengaduan dan Pemantauan Media Se-Indonesia Tahun 2011-2016 [Internet]. 2016 [cited 2018 Dec 20]. Available from:

http://bankdata.kpai.go.id/tabula si -data/data-kasus-seindonesia/data-kasusperlindungan-anak-berdasarkanlokasi-pengaduan-danpemantauan-media-seindonesia-tahun-2011-2016

5. KPAI. Bali Masuk 10 Besar Kekerasan Anak [Internet]. 2015 [cited 2018 Dec 20]. Available from: http://www.kpai.go.id/berita/kpa 
Ni Gusti Ayu Santika Dewi, Putu Susy Natha Astini, Ida Erni Sipahutar.

Desember 2020.13 (2).59-68

i-bali-masuk-10-besarkekerasan-anak

6. Gianyar DP. Kasus Kekerasan Melibatkan Anak Meningkat [Internet]. 2018 [cited 2018 Dec 20]. Available from: http://www.nusabali.com/berita $13 \quad 7831 /$ kasus-kekerasanmelibatkan-anak-meningkat.

7. Neherta M. Modul Intervensi Pencegahan Kekerasan Seksual Terhadap Anak [Internet]. Andalas: Fakultas Kesehatan Masyarakat; 2017. Available from:

http://repo.unand.ac.id/12886/1 /Pe\%0Ancegahan-kekerasanseksual-\%0Aterhadap anak.pdf.

8. Andarmoyo S. Psikoseksual dalam Pendekatan Konsep dan Proses Keperawatan. Yogyakarta: Ar-Ruzz Media; 2012.

9. Darmayanti M, Arni C. Layanan Informasi dengan Media Gambar untuk Meningkatkan Pemahaman Sex Education Siswa. Indones J Guid Couns Theory Appl [Internet]. 2018;7(1). Available from:

https://journal.unnes.ac.id/sju/i nde

x.php/jbk/article/download/178 79/ 10848

10. Bandura. Social Kognitive Theory: An Agentic Perspective. California; 2001.

11. Mukhid A. Perspektif Teori Kognitif Sosial dan Implikasinya terhadap Pendidikan. Tadris. 2009;4(1):106-22.
12. Ahmadi A, Sholeh M. Psikologi Perkembangan. Jakarta: PT RIneka Cipta; 2005.

13. Notoatmodjo S. Promosi Kesehatan Teori dan Aplikasi. Jakarta: Rineka Cipta; 2010.

14. Hakim M, Anugrahwati R. Efektivitas Komik Terhadap Self Efficacy Upaya Pencegahan Kekerasan Pada Anak Usia Sekolah. J Care [Internet]. 2017;5(3):359-68. Available from:

http://jurnal.unitri.ac.id/index.ph $\mathrm{p} /$

care/article/download/704/687

15. Laksana S. Komik Pendidikan Sebagai Media Inofatif MI/SD. Ta'allum [Internet]. 2015;3(2):151-62. Available from:

https://www.researchgate.net/pu bl $\% 0 \mathrm{~A}$ \%0A\%0Aication/315408500_ko mik_pendid

ikan_sebagai_media_inofatif_m is $\mathrm{d}$ 